\title{
Mineral-Deficiency Symptoms Displayed by Papaya Plants Grown under Controlled Conditions $^{1}$
}

\author{
Héctor R. Cibes and Socorro Gaztambide ${ }^{2}$
}

ABSTRACT

\begin{abstract}
Deficiency symptoms caused by lack of macro- and micronutrient elements were induced on papaya trees grown in sand culture in the greenhouse. The elements used in the study were N, P, K, Ca, Mg, S, Fe, Mn, and B. Lack of N and $P$ depressed overall growth markedly, while the absence of $K$ and $\mathrm{Ca}$ caused pronounced foliar symptoms. Among the micronutrients, B deficiency had the greatest influence in depressing growth and root development. Deficiencies of $S$, $\mathrm{Fe}, \mathrm{Mg}$, and $\mathrm{Mn}$ failed to retard growth or root development. Flowers set under the minus K, S, Mg, Mn, and the complete solution treatments. However, only the plants in the minus $K$ and minus $M n$ treatments produced fruits. The concentration of the particular missing element in leaf tissues was lower in plants from the respective deficiency treatment than in control plants. Plants in the minus $B$ treatment showed abnormal growth, reminiscent of papaya plants affected by the bunchy-top disease. However, latex flow was normal in B-deficient plants.
\end{abstract}

\section{INTRODUCTION}

Papaya (Carica papaya L.) is a popular fresh and processing fruit in Puerto Rico. In 1973-74, the main wholesale markets of the Island sold 50,000 cwt of green papaya fruits for local consumption, valued at $\$ 250,000$. In the same fiscal year $4,805 \mathrm{cwt}$ of green fruit: were shipped to the United States. These figures do not include the papaya used in canned papaya nectar and candied papaya, which are sold locally and exported to the United States. In a study conducted in 1972, it was found that the canned food factories bought for the above purpose $20,090 \mathrm{cwt}$ of fresh fruits for which they paid $\$ 133,789$.

No publication is available in Puerto Rico to help papaya growers determine if their plants are affected by mineral deficiencies and to identify these deficiencies through their symptoms. For horticulturists and plant nutritionists, no publications were found giving descriptions of the mineral deficiencies and their relative influence on growth and nutrient composition of the papaya tree.

The object of this study was to provide this needed information, by developing and recording major and minor element deficiency symptoms in the papaya under controlled conditions.

\section{MATERIALS AND METHODS}

The experiment was conducted in the greenhouse. Deficiencies of $\mathrm{N}$, $\mathrm{P}, \mathrm{K}, \mathrm{Ca}, \mathrm{Mg}, \mathrm{S}, \mathrm{Fe}, \mathrm{Mn}$, and $\mathrm{B}$ were induced on papaya plants grown in

${ }^{1}$ Manuscript submitted to Editorial Board February 13, 1978.

${ }^{2}$ Plant Physiologist, and Assistant Chemist, respeciivoly, Agricultural Experiment Station, Mayaguez Campus, University of Puerto Rico, Río l'iedras, P.R. 
sand culture. For this purpose 30 five-gallon self-drained glazed stone crocks were filled with nutrient-free white quartz sand. The procedure used for purifying the sand is described elsewhere. ${ }^{3}$ A single 1-mo-old papaya seedling of the variety Solo was planted in the center of each crock. Three replicates were used per treatment.

Except for minor details, the procedure followed was the same as that previously used for coffee. ${ }^{3}$ However, to aid the reader in following the discussion of the results obtained, the composition of the nutrient solutions used for the differential treatments are given in table 1. At first, the solutions were applied at the rate of 1 qt twice a week. Meanwhile the sand was kept moist with distilled water. As soon as the plants resumed growth, the solutions were applied every other day, and then daily for the duration of the experiment.

The experiment was terminated at the end of 6 mo. Green and dry weights of the tops and roots of the trees on each treatment were taken. Written records and color transparencies were made of all deficiency symptoms, as these advanced through progressive stages of development. Leaf and stem samples were analyzed. The samples intended for chemical analysis were dried to constant weight at $70^{\circ} \mathrm{C}$, ground, and stored in bottles.

\section{RESULTS AND DISCUSSION}

GROWTH AND YIELD

The effect of the various treatments upon the growth of the papaya plants are presented in table 2. The greatest reduction in growth was observed with the minus- $\mathrm{N}$ treatment. The omission of no other element from the growing medium caused such a drastic reduction in growth as did the lack of $\mathrm{N}$. This reduction included both tops and roots. With the exception of the minus $\mathrm{K}$, the top-root ratio produced by the omission of $\mathrm{N}$ was the highest. The second largest reduction in aerial growth of plants was caused by the absence of P. However, the root systems of these plants looked healthy and attained good growth and development, to the extent that their dry weights were higher than those of the corresponding tops. The decrease in total growth due to the lack of $\mathrm{K}$ ranked third. Plants affected by $\mathrm{K}$ deficiency developed poor root systems in contrast to the abundant growth of the aerial parts. This treatment produced the widest top-root ratio of all, including the minus $\mathrm{N}$. If the total weight of plants is used as the growth criterion, then the minus- $\mathrm{K}$ treatment induced slightly greater decrease in growth than the minus-Ca, mostly due to the poor production of roots. However, when the treatments are

${ }^{3}$ Cibes, H., and Samuels, G., 1955. Mineral-deficiency symptoms displayed by coffee trees grown under controlled conditions, Agric. Exp. Stn., Univ. P.R. Tech. Paper No. 14. 
TABLE 1.-Composition of nutrient solution used in papaya mineral deficiency experiment

\begin{tabular}{|c|c|c|c|c|c|c|c|c|c|c|c|c|c|c|}
\hline \multirow[b]{2}{*}{ Treatment } & \multicolumn{9}{|c|}{ Partial volume molecular concentration of- } & \multicolumn{5}{|c|}{ Parts per million of- } \\
\hline & $\mathrm{Ca}\left(\mathrm{NO}_{3}\right)_{2}$ & $\mathrm{MgSO}_{4}$ & $\mathrm{KH}_{2} \mathrm{PO}_{4}$ & $\mathrm{CaCl}_{2}$ & $\mathrm{NaH}_{2} \mathrm{PO}_{4}$ & $\mathrm{NaNO}_{3}$ & $\mathrm{~K}_{2} \mathrm{SO}_{4}$ & $\mathrm{KNO}_{3}$ & $\mathrm{Mg}\left(\mathrm{O}_{3}\right)_{2}$ & $\begin{array}{c}\mathrm{Fe} \\
\text { Seques- } \\
\text { trene }\end{array}$ & $\mathrm{H}_{3} \mathrm{BO}_{3}$ & $\mathrm{MnSO}_{4}$ & $\mathrm{ZnSO}_{4}$ & $\mathrm{CuSO}_{4}$ \\
\hline Complete & 0.009 & 0.0045 & 0.0045 & & & & & & & 5 & 0.5 & 0.5 & 0.05 & 0.02 \\
\hline Minus N & & .0045 & .0045 & 0.009 & & & & & & 5 & .5 & .5 & .05 & .02 \\
\hline Minus $\mathrm{K}$ & .009 & .0045 & & & 0.0045 & & & & & 5 & .5 & .5 & .05 & .02 \\
\hline Minus P & .009 & .0045 & & & & & 0.0023 & & & 5 & .5 & .5 & .05 & .02 \\
\hline Minus Ca & & .0045 & .0045 & & & 0.0045 & & 0.0045 & & 5 & .5 & .5 & .05 & .02 \\
\hline Minus Mg & .009 & & .0045 & & .0045 & & & & & 5 & .5 & .5 & .05 & .02 \\
\hline Minus $S$ & .009 & & .0045 & & & & & & 0.0023 & 5 & .5 & $.5^{1}$ & $.05^{1}$ & $.02^{i}$ \\
\hline Minus $\mathrm{Fe}$ & .009 & .0045 & .0045 & & & & & & & - & .5 & .5 & .05 & .02 \\
\hline Minus B & .009 & .0045 & .0045 & & & & & & & 5 & - & .5 & .05 & .02 \\
\hline Minus Mn & .009 & .0045 & .0045 & & & & & & & 5 & .5 & - & .05 & .02 \\
\hline
\end{tabular}

'The chloride instead of the sulfate of the indicated element was used. 
compared on the basis of their top growth, the minus-Ca treatment induced a much greater reduction in growth than the minus $\mathrm{K}$. The minus $\mathrm{Mg}, \mathrm{S}, \mathrm{Fe}$, and $\mathrm{Mn}$ treatments did not cause any appreciable decrease in either top or root growth. On the other hand, the omission of $\mathrm{B}$ did reduce growth of the aerial portion of affected plants to a considerable extent. The reduction in top growth gave the boron-deficient treatment plants a peculiar bunchy top appearance, which will be discussed later.

Plants in the minus $\mathrm{K}, \mathrm{Mg}, \mathrm{S}, \mathrm{Mn}$, and the complete treatment produced flowers, but only those lacking $\mathrm{K}$ and $\mathrm{Mn}$ set fruits.

The ranking of the adverse effects, expressed in decreasing order, of the omission of each mineral element on the growth of the papaya trees, was as follows:

$$
\begin{aligned}
& \text { Roots-N }>\mathrm{K}>\mathrm{P}>\mathrm{B}>\mathrm{Mn}>\mathrm{Ca}>\mathrm{Mg}>\mathrm{S}>\text { Complete }>\mathrm{Fe} \\
& \text { Tops-N }>\mathrm{P}>\mathrm{Ca}>\mathrm{B}>\mathrm{K}>\mathrm{Mn}>\mathrm{Complete}>\mathrm{Mg}>\mathrm{Fe}>\mathrm{S} \\
& \text { Total-N }>\mathrm{P}>\mathrm{K}>\mathrm{Ca}>\mathrm{B}>\mathrm{Mn}>\mathrm{Mg}>\text { Complete }>\mathrm{S}>\mathrm{Fe} \\
& \text { Leaves-N }>\mathrm{P}>\mathrm{Ca}>\mathrm{B}>\mathrm{K}>\mathrm{Mg}>\mathrm{Mn}>\text { Complete }>\mathrm{Fe}>\mathrm{S} \\
& \text { Stems-N }>\mathrm{P}>\mathrm{Ca}>\mathrm{K}>\mathrm{B}>\mathrm{Mn}>\text { Complete }>\mathrm{Mg}>\mathrm{Fe}>\mathrm{S}
\end{aligned}
$$

TABLE 2.-Effect of mineral deficiencies on dry weight $(\mathrm{gm})$ of papaya trees

\begin{tabular}{lrrrrrr}
\hline \multicolumn{1}{r}{ Treatment } & Leaves & Stem & Tops & Roots & $\begin{array}{c}\text { Total (Roots } \\
\text { and tops) }\end{array}$ & $\begin{array}{c}\text { Top: root ra- } \\
\text { tios }\end{array}$ \\
\hline Complete & 357 & 184 & 541 & 359 & 900 & $1.5: 1$ \\
Minus N & 13 & 6 & 19 & 7 & 26 & $2.7: 1$ \\
Minus P & 78 & 59 & 137 & 147 & 284 & $.9: 1$ \\
Minus K & 298 & 120 & 418 & 114 & 532 & $3.7: 1$ \\
Minus Ca & 169 & 112 & 281 & 299 & 580 & $.9: 1$ \\
Minus Mg & 331 & 219 & 550 & 309 & 859 & $1.8: 1$ \\
Minus S & 428 & 236 & 664 & 348 & 1,012 & $2.2: 1$ \\
Minus Fe & 397 & 234 & 631 & 567 & 1,198 & $1.1: 1$ \\
Minus Mn & 339 & 180 & 519 & 265 & 784 & $1.9: 1$ \\
Minus B & 239 & 134 & 573 & 229 & 602 & $2.5: 1$ \\
\hline
\end{tabular}

LEAF AND STEM ANALYSES

The results of the leaf and stem analyses of the papaya trees submitted to the various treatments are given in table 3 . In all cases, the treatment in which a particular element was omitted gave lower leaf and stem values than did the complete nutrient solution for the same element. The percentage decrease in leaf and stem nutrient content for the deficient treatments, as compared to the complete treatment, is shown in table 4 . Further discussion on the foliar and stem analyses will be presented in subsequent discussion of mineral elements in these two portions of the trees, as induced by the various treatments. 


\section{Nitrogen}

$\mathrm{P}$ content was the highest in both leaf and stem tissues of the $\mathrm{N}$ deficient plants. The $\mathrm{P}$ level in leaves and stems of minus- $\mathrm{N}$ plants was 2.36 and $1.90 \%$, respectively. The corresponding percentages for the complete solution treatment were 0.82 and 0.98 . Apparently, $\mathrm{K}$ tended to accumulate in very high amounts in the stem. The amount of this element in the stem was 3.4 times higher than in the leaf, and 3.7 times that of the plants grown in complete solution. The behavior of Ca was the opposite. Although $\mathrm{Ca}$ was present in high quantity in the stem, its content in the

TABLE 3.-Analysis of parts of papaya plants on a dry-weight basis

\begin{tabular}{|c|c|c|c|c|c|c|c|c|c|}
\hline \multirow{2}{*}{ Treatment } & \multicolumn{9}{|c|}{$\begin{array}{c}\begin{array}{c}\text { Leaf and stem content of nutrient elements in papaya plants grown under various } \\
\text { deficiency regimes, dry-weight basis }\end{array}\end{array}$} \\
\hline & $\mathrm{N}$ & P & $\mathrm{K}$ & $\mathrm{Ca}$ & $\mathrm{Mg}$ & $S$ & $\mathrm{Fe}$ & $\mathrm{Mn}$ & $\mathrm{B}$ \\
\hline & $\%$ & $\%$ & $\%$ & \% & $\%$ & $\%$ & $P / m$ & $P / m$ & $P / m$ \\
\hline & \multicolumn{9}{|c|}{ Leaves } \\
\hline Minus $N$ & 1.96 & 2.36 & 1.70 & 4.56 & 2.13 & 1.30 & 263 & 182 & 206 \\
\hline Minus $\mathrm{P}$ & 2.58 & .14 & 1.68 & 3.69 & 1.87 & 1.31 & 554 & 113 & 139 \\
\hline Minus K & 3.46 & 1.49 & .40 & 3.61 & 2.21 & 1.34 & 192 & 97 & 109 \\
\hline Minus $\mathrm{Ca}$ & 2.00 & 1.14 & 2.52 & 1.48 & 1.97 & 1.28 & 292 & 143 & 163 \\
\hline Minus $\mathrm{Mg}$ & 2.82 & .80 & 2.75 & 3.30 & .30 & 1.31 & 331 & 40 & 131 \\
\hline Minus S & 2.64 & .76 & 1.44 & 3.89 & 1.37 & 0.54 & 233 & 55 & 148 \\
\hline Minus $\mathrm{Fe}$ & 2.15 & .96 & 1.54 & 3.93 & 2.11 & 1.25 & 140 & 83 & 113 \\
\hline Minus Mn & 2.38 & .96 & 1.70 & 3.80 & 1.14 & 1.05 & 317 & 16 & 122 \\
\hline Minus B & 2.65 & 1.04 & 2.10 & 3.92 & 1.43 & 1.08 & 179 & 88 & 26 \\
\hline \multirow[t]{2}{*}{ Complete } & 2.25 & .82 & 1.58 & 3.61 & 1.21 & 1.21 & 252 & 88 & 109 \\
\hline & \multicolumn{9}{|c|}{ Stemis } \\
\hline Minus $N$ & 0.65 & 1.90 & 5.80 & 3.03 & 0.70 & 0.42 & 91 & 73 & - \\
\hline Minus $\mathrm{P}$ & 1.54 & .07 & 2.64 & 1.19 & .36 & .46 & $6 \overline{0}$ & 48 & $2 \overline{0}$ \\
\hline Minus K & 1.46 & 1.28 & .22 & 1.00 & 1.21 & 1.02 & 38 & 49 & 23 \\
\hline Minus $\mathrm{Ca}$ & .70 & .84 & 3.48 & .51 & .70 & .54 & 73 & 50 & 29 \\
\hline Minus $\mathrm{Mg}$ & 1.30 & 1.11 & .92 & 1.96 & .14 & 1.24 & 76 & 28 & 29 \\
\hline Minus $\mathrm{S}$ & 1.93 & .96 & 1.88 & 1.51 & .80 & .33 & 89 & 17 & 27 \\
\hline MinusFe & 1.32 & 1.00 & 2.05 & 1.74 & .45 & 1.06 & 69 & 44 & 28 \\
\hline Minus Mn & 1.65 & 1.08 & 2.08 & 2.15 & .91 & .72 & 86 & 1 & 28 \\
\hline Minus B & 2.18 & 1.04 & 3.02 & 1.71 & .65 & .76 & 147 & 38 & 16 \\
\hline Complete & 1.33 & .98 & 2.22 & 1.43 & .97 & .92 & 90 & 24 & 25 \\
\hline
\end{tabular}

leaf of minus- $\mathrm{N}$ trees was considerably higher. The Ca level in these trees was the highest of all treatments. The percentage of $\mathrm{Mg}$ in the leaves was also high, compared to that of the stem; $\mathrm{Mg}$ was also lower in the complete than in most of the other treatments. Among the minor elements, Mn and B were present in higher amounts in the leaves of the minus- $\mathrm{N}$ treatment than in the complete treatment. 


\section{Phosphorus}

The $\mathrm{N}, \mathrm{K}, \mathrm{Ca}, \mathrm{Mg}, \mathrm{S}, \mathrm{Mn}$, and $\mathrm{B}$ content of leaves in the minus- $\mathrm{P}$ treatment was more or less the same as that of the full-nutrient treatment. However, the leaf $\mathrm{Fe}$ in these plants was 2.2 times higher than in the complete treatment. The $\mathrm{K}$ level of the stem, as in the minus- $\mathrm{N}$ treatment, was somewhat higher than in the leaves of the same plants. Table 3 shows the tendency for $\mathrm{Mg}, \mathrm{S}, \mathrm{Fe}$, and $\mathrm{Mn}$ to accumulate in much higher degree in the leaves than in the stem.

\section{Potassium}

The highest $\mathrm{N}$ value occurred in the leaves of trees lacking $\mathrm{K}$. The $\mathrm{N}$ content of these leaves was $3.46 \%$ in contrast with $2.25 \%$ for the complete treatment, i.e., about 1.5 times higher. $\mathrm{P}$ and $\mathrm{Mg}$ were also very high in

TABIE 4.--Percentage decrease in leaf and stem nutrient content, comparing deficient to complete treatment and related dry weights

\begin{tabular}{|c|c|c|c|c|}
\hline \multirow{2}{*}{ Treatment } & \multicolumn{2}{|c|}{ Decrease in nutrient content of } & \multicolumn{2}{|c|}{ Decrease in dry weight of } \\
\hline & Leaf & Stem & Leaf & Stem \\
\hline & \multicolumn{2}{|c|}{$\%$} & \multicolumn{2}{|c|}{$\%$} \\
\hline Minus N & 13 & 51 & 96 & 97 \\
\hline Minus $\mathrm{P}$ & 83 & 93 & 78 & 68 \\
\hline Minus $\mathrm{K}$ & 75 & 90 & 16 & 35 \\
\hline Minus $\mathrm{Ca}$ & 59 & 64 & 53 & 39 \\
\hline Minus Mg & 75 & 86 & 7 & +19 \\
\hline Minus $\mathrm{S}$ & 55 & 64 & $+20^{1}$ & +28 \\
\hline Minus $\mathrm{Fe}$ & 44 & 24 & +11 & +27 \\
\hline Minus $\mathrm{Mn}$ & 82 & 58 & 5 & 2 \\
\hline Minus B & 76 & 36 & 33 & 27 \\
\hline Complete & 0 & 0 & 0 & 0 \\
\hline
\end{tabular}

'A plus indicates an increase.

this portion of $\mathrm{K}$-deficient plants. In the stem tissues, the $\mathrm{P}, \mathrm{Mg}$, and $\mathrm{Mn}$ content was relatively higher than with the complete solution, while $\mathrm{Ca}$ and $\mathrm{Fe}$ values were lower.

\section{Calcium}

The lowest amount of $\mathrm{N}$, under any treatment other than the minus$\mathrm{N}$, occurred in the Ca-deficient trees. This was true for both leaves and stems of plants in this treatment. In the stem, the $\mathrm{N}$ content was nearly as low as that of the minus- $\mathrm{N}$. The leaf $\mathrm{N}$ of the complete treatment was about 1.6 times that of the corresponding minus-Ca treatment. P, K, and $\mathrm{Mg}$ were also present in high amounts in the leaves, as compared to the controls. The accumulation of nutrient elements in the stems was very low for $\mathrm{P}, \mathrm{Mg}, \mathrm{S}$, and $\mathrm{Fe}$, while $\mathrm{K}$ was 1.56 higher than in the complete treatment. 


\section{Magnesium}

$\mathrm{N}, \mathrm{K}, \mathrm{S}, \mathrm{Fe}, \mathrm{Mn}$, and $\mathrm{B}$ content of leaves from trees lacking $\mathrm{Mg}$ was relatively higher than in the complete treatment. $\mathrm{P}$ attained a higher concentration in the stem portion of these plants than in the leaf tissue. $\mathrm{K}$ accumulated in exceedingly low amounts in the stem, as compared with the content of this element in the leaf, which was the highest for all deficiencies. No other treatment, except the minus-K, showed a lower level of this element in the stem. In fact, the leaf $\mathrm{K}$ of plants lacking $\mathrm{Mg}$ was three times that of the stem. Ca and $\mathrm{S}$ values in the stem were much higher than in the check.

\section{Sulfur}

The leaves of plants in the minus-S treatment had a higher accumulation of $\mathrm{N}, \mathrm{Ca}, \mathrm{Mg}$, and $\mathrm{B}$ than those of the check plants. The stem tissue had a higher $\mathrm{N}$ level and a much lower Mn content than the check. $\mathrm{P}$ and $\mathrm{K}$ were at higher concentrations in the stem than in the leaves. The characteristic tendency of $\mathrm{Ca}$ to concentrate in the leaf tissue rather than in the stem was manifest.

\section{Iron}

There were few marked variations in the nutrient levels in either the leaves or stems of plants grown under lack of Fe. Generally speaking, these tended to accumulate in higher amounts in the leaves than in the stems. Ca was present in much higher amounts in both plant portions than in the full-nutrient treatments. Fe, Mn, and B contents of leaves exceeded those of the stem.

\section{Manganese}

Mn-deficient plants had relatively higher concentrations of $\mathrm{Ca}$ and $\mathrm{Fe}$ in the leaves than the check plants. Except for P and K, all other nutrient elements tended to accumulate at higher concentrations in the leaves than in the stems. Differences in nutrient concentrations in the stem between $\mathrm{Mn}$-deficient plants and those in the complete solution were not striking. The most pronounced effect of this treatment was that the stems of the affected trees were practically devoid of Mn. Apparently, all residual Mn originally contained by the papaya seedlings, was translocated to the leaves.

\section{Boron}

Boron deficiency induced accumulation of $\mathrm{N}, \mathrm{P}, \mathrm{K}, \mathrm{Ca}$, and $\mathrm{Mg}$ in the leaves and in the stem. The content of all elements, except $\mathrm{K}$, was higher in the leaves than in the stem. 
NUTRIENT DEFICIENCY-WEIGHT RELATIONSHIPS

Table 4 shows the percentage decrease in leaf and stem nutrient contents and related dry weights when deficient treatments are compared to complete treatments. The percentage decreases in nutrient content of the leaf were not as marked for minus- $\mathrm{N}$ as was the decrease in leaf and stem weight. $\mathrm{P}$ and $\mathrm{Ca}$ deficiencies showed rather similar decreases in nutrient and dry-weight values. Omission of $\mathrm{K}$, on the other hand, induced large decreases in leaf and stem values, despite small to moderate decreases in dry weight. The minus- $\mathrm{Mg},-\mathrm{S},-\mathrm{Fe}$ and $-\mathrm{Mn}$ treatments all showed larger decreases in nutrient content than in dry weight. The plants in the minus- $\mathrm{Mg}$, $-\mathrm{S}$, and -Fe treatments showed sizeable decreases in nutrient contents, and yet they showed actual increases in dry weight in relation to the complete solution treatment.

VISUAL DEFICIENCY SYMPTOMS

\section{Nitrogen}

The symptoms caused by the absence of $\mathrm{N}$ from the nutrient solution were the first to appear and were evident a short time after the differential treatments were initiated. These symptoms were first noticeable on the older leaves, which turned from a deep-green to a yellowish-green color. As the deficiency progressed all the foliage turned completely yellow (Plate I, Fig. a). Lack of $\mathrm{N}$ also affected the size and shape of the leaves. Leaves from plants in the complete solution were considerably more lobed than their $\mathrm{N}$-deficient counterparts. The $\mathrm{N}$ deficiency also had a pronounced effect upon the growth of trees. Figure b illustrates the relative size of the $\mathrm{N}$-starved plants, as compared to those in the complete solution.

\section{Phosphorus}

The foliar deficiency symptoms due to the lack of $\mathrm{P}$ also appeared first in the older leaves, which showed a yellow mottling along the margins.

Plate I, fig. a, Nitrogen-deficient papaya leaf showing yellow color and reduced size as compared to the complete leaf; fig. $b$, Nitrogen-deficiency was characterized by a chlorosis of older leaves and stunted growth; fig. c, Papaya leaves under phosphorus deficiency showing yellow discolorations along margins; fig. d, Lack of phosphorus reduced plant growth markedly; fig. e, Potassium deficiency symptoms in the leaves were characterized by a chlorosis and drying from the tip inward; fig. f, Potassium-deficient tree showing chlorotic leaves in a hanging-down position; fig. g, Papaya leaf displaying olive-green color with yellow splotches characterizing calcium deficiency; fig. h, Papaya tree deficient in calcium showing bare appearance due to defoliation; fig. i, Papaya tree showing green color with mottling and necrotic spots associated with magnesium deficiency; fig. j, Omission of iron from nutrient solution induced severe chlorosis in young leaves; fig. $\mathrm{k}$, Iron-deficient tree showing stem dieback; fig. l, Chlorosis displayed by leaves of manganese deficient plants; fig. $\mathrm{m}$, Malformed leaf characteristics of minus boron treatment; fig. $n$, Growth practically ceased in boron-deficient trees giving them a "bunchy top" appearance. 

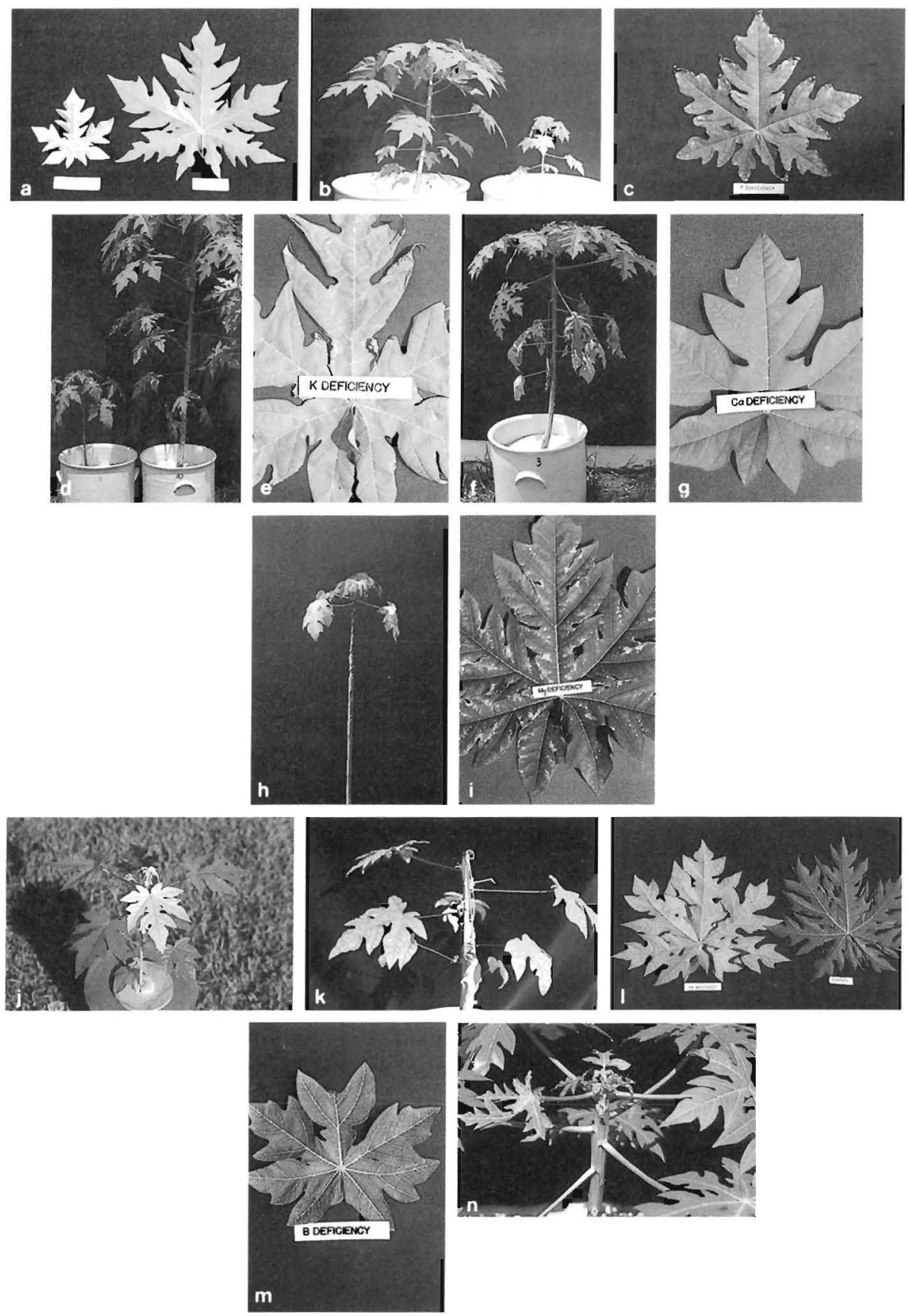
As the deficiency became acute, the mottled areas turned necrotic and the lobe tips and margins rolled upward (fig. c). Finally, these leaves yellowed completely and abscised. The younger leaves were small and deep green in color.

The absence of $\mathrm{N}$ from the nutrient medium reduced markedly the growth and development of the plants (fig. d), which were stunted, had very thin stems and short internodes.

\section{Potassium}

The $\mathrm{K}$ deficiency symptoms were also quick to appear. These were evident right after those of $\mathrm{N}$. The first indication of $\mathrm{K}$ hunger was the angle at which the peduncle grew in relation to the stems. In the normal plants the leaves were disposed at a somewhat acute or slightly upright position along the stem, while in the $\mathrm{K}$-deficient trees these tended to grow at an oblique position (fig. f). Following the appearance of the above-stated symptoms the older leaves turned greenish-yellow with a slight marginal necrosis in some of the deep lobes (fig. e). The leaves tended to dry from the tip toward the center giving the plant a ragged appearance. The typical green-brownish color developed by these trees may have been due to high $\mathrm{N}$ accumulation as is shown in table 3 .

\section{Calcium}

Symptoms of Ca deficiency appeared almost simultaneously with those of $\mathrm{K}$. The leaves of trees affected by the lack of $\mathrm{Ca}$ turned light olive green with yellow splotches scattered about the lamina (fig. g). However there were no necrotic spots as in the case of the minus-Mg leaves. These leaves also developed fewer lobes than those from the complete solution (fig. g). In the more advanced stages, the leaves turned completely yellow. By the end of the experiment, most of the leaves had abscised, only a few remaining attached to the apical portion of the stem (fig. h).

\section{Magnesium}

The first evidence of $\mathrm{Mg}$ deficiency appeared near the margins of older leaves as small numerous necrotic spots (fig. i). With time, these spots coalesced to form larger straw-colored areas. However, the interveinal space of such leaves remained green.

\section{Sulfur}

The only deficiency symptom displayed by papaya trees grown without $\mathrm{S}$ was a slight yellowing of the leaves. Since there was no reduction in growth of plants it can be surmised that the deficiency symptoms due to lack of $\mathrm{S}$ were mild. 
Iron

The deficiency symptoms developed under lack of Fe were very severe. The symptoms started to appear in the younger leaves. At the incipient stage the leaves turned pale yellow. With the passage of time the pale yellow became deep yellow, and finally the leaves became almost white (fig. j). Soon after the uppermost leaves became bleached the apical portion of the stem broke down and turned necrotic. Figure k shows one of the minus-Fe plants with dead apex.

\section{Manganese}

Although the lack of $\mathrm{Mn}$ did not affect the growth of plants, they showed definite symptoms of Mn malnutrition. At first the deficiency was characterized by a mild chlorosis of the leaves accompanied by a mottling along the interveinal areas. In a more advanced stage these leaves turned yellow (fig, 1).

\section{Boron}

Boron deficiency" produced a very interesting and peculiar growth behavior in the papaya tree. The leaves failed to grow to normal size and were dark green and leathery with part of the lamina misshapen (fig. m). Elongation of the stem practically ceased, giving the tree a bunchy top appearance. The general aspect of B-deficient trees was very similar to that of trees affected by the bunchy top disease, ${ }^{4}$ except that the tops of these trees exuded latex when pricked, which is not the case with trees affected by the bunchy top disease (fig. $n$ ).

\section{RESUMEN}

Síntomas carenciales, tanto de macro como de microelementos, se indujeron en papayos bajo condiciones controladas de invernadero. Se estudiaron carencias de $\mathrm{N}, \mathrm{P}, \mathrm{K}, \mathrm{Ca}, \mathrm{Mg}$, $\mathrm{S}, \mathrm{Fe}, \mathrm{Mn}$ y B. Las plantas testigo se regaron con una solución completa. Las carencias de $\mathrm{N}$ y $\mathrm{P}$ redujeron grandemente el crecimiento de las plantas asi tratadas, mientras que la ausencia de $\mathrm{K}$ y de Ca ocasionó síntomas carenciales muy pronunciados en el follaje. Entre los microelementos, la carencia de boro causó la mayor reducción en el crecimiento de los tallos y desarrollo de raíces. En cambio, la carencia de $\mathrm{S}, \mathrm{Fe}, \mathrm{Mn}$ y $\mathrm{Mg}$ no afectó adversamente el crecimiento de tallos y raices. Las plantas carentes de K, S, Mg, Mn y los testigos florecieron, pero solamente las carentes de potasio y manganeso cuajaron frutas. El contenido en cada uno de los elementos deficitarios, tanto en las hojas como en los tallos de las plantas afectadas, fue considerablemente menor que el correspondiente a los testigos. Los síntomas carenciales que mostraron las plantas carentes de boro se asemejaban mucho a los que caracterizan la enfermedad conocida como "bunchy top", a excepción de que el flujo de látex en este caso no se interrumpió, como sucede en las plantas afectadas por la enfermedad.

${ }^{4}$ Bird, J., and Adsuar, J., 1952. Viral nature of papaya bunchy top, J. Agric. Univ. P.R. 36(1): 5-11. 